\title{
Quality characteristics of barley-Makgeolli fermented from yeast Y204 with different fermented agents
}

\author{
Sun Hee Kim, Ji-Young Mun, Joo-Yeon Kim, So Young Kim, Soo-Hwan Yeo* \\ Fermented and Processed Food Science Division, National Institute of Agricultural Science, RDA, Wanju 55365, Korea
}

\section{발효제를 달리한 효모 Y204로 빚은 보리 막걸리의 품질 특성}

\author{
김순희 · 문지영 · 김주연 · 김소영 · 여수환* \\ 농촌진흥청 국립농업과학원 농식품자원부 발효가공식품과
}

\begin{abstract}
In this study, we compared the quality characteristics of barley-Makgeolli prepared with different nuruk fermentation starters for Saccharomyces cerevisiae Y204 at various temperatures $\left(15,20\right.$ and $\left.25^{\circ} \mathrm{C}\right)$ and for different fermentation periods. The $\mathrm{pH}$ of the barley-Makgeolli produced by the nuruk of $A$. oryzae 75-2 (AO) was in the 6.4-4.9 range, which is significantly different to that (3.7-3.3) of the barley-Makgeolli produced using the nuruk of $A$. luchuensis 74-5 (AL). Barley-Makgeolli exhibited $0.2 \%$ acidity when prepared using $\mathrm{AO}$, and $0.8 \%$ with AL. The amino-acid content increased on the second day of fermentation and was smoothly maintained to the end of the fermentation period, except when fermented at $25^{\circ} \mathrm{C}$. The sugar content of $\mathrm{AO}$ Makgeolli was significantly higher than that of AL Makgeolli. Saccharomyces cerevisiae Y204 showed good alcohol fermentation (15-16\%) at $25^{\circ} \mathrm{C}$ for both AO and AL barley-Makgeolli. The malic acid content of the organic acids increased with increasing fermentation temperature and the citric acid content was the highest in AL barley-Makgeolli when fermented at low temperature. The aroma component patterns of each barley Makgeolli was able to predict the diversity of each flavor pattern on the basis of differences in the $\mathrm{AO}$ and $\mathrm{AL}$ fermentation groups and temperature. Therefore, barley-Makgeolli produced by Y204 is expected to exhibit superior quality due to the good alcohol producing ability of the Y204 yeast.
\end{abstract}

Key words : starter, nuruk, barley-Makgeolli, fermentation, quality

\section{서 론}

전통적으로 빚어 온 우리 고유의 막걸리는 누룩곰팡이 및 효모에 의한 병행복발효 공정을 거치면서 술덧의 구성성 분과 새로운 생성물로 인하여 소주와 맥주 등과 달리 생체 내 신진대사에 관여하는 생리활성물질이 함유되어 있어 영양학적으로 우수하다(1). 막걸리는 지역에 따라 사용하 는 전분질 원료(찹쌀, 멥쌀, 보리쌀, 현미, 옥수수, 고구마,

*Corresponding author. E-mail : yeobio@korea.kr Phone : 82-63-238-3609, Fax : 82-63-238-3843

Received 16 July 2019; Revised 20 August 2019; Accepted 04 September 2019.

Copyright (c) The Korean Society of Food Preservation. All rights reserved.
밀 등)가 다양하고 발효제인 곡자(누룩)을 첨가하여 발효시 킨 것으로 술덧을 혼탁하게 제성한 대표적인 전통주이다 (2-4). 이는 단맛, 신맛, 쓴맛, 매운맛과 청량감이 있고 다른 시판 주류보다 알코올 도수가 비교적 낮은 $6 \%$ 정도이지만, 주세법 개정을 통한 $12-18 \%$ 의 프리미엄 막걸리도 출시되 고 있다 $(5,6)$. 최근, 소비자 만족도를 향상시키기 위한 일환 으로 영양이나 기능성을 고려한 다양한 잡곡류 또는 과일 원료 즉, 조, 수수, 팥, 흑미, 현미, 찹쌀, 고구마 등과 감, 석류, 포도, 블루베리, 오미자, 꾸지뽕, 크랜베리, 아로니아 등의 부재료를 이용한 주류 연구가 활발히 이루어지고 있지 만 보리를 이용한 막걸리 연구는 저조한 실정이다.

한편, 잡곡류의 대표 품종인 보리(Hordeum vulgare L.)는 쌀과 함께 우리나라의 주곡 농산물로 알려져 있으며 쌀과 달리 보리만이 갖는 특성이 있다. 국내에서 생산되는 보리 
는 추운 겨울철부터 재배하기 때문에 다른 작물에 비해 병충해가 심하지 않아 농약을 살포할 필요성이 거의 없기 때문에 무공해 식량자원으로 그 가치가 높다. 또한 보리는 백미에서 부족하기 쉬운 단백질(9.5-11.8\%)은 물론 비타민 $\mathrm{B}$ 와 나이아신이 쌀에 비해 1.5-2배 이상 함유되어 있다. 한국인들에게 부족하기 쉬운 철과 칼슘 함량은 쌀보다 각각 5 배, 8 배나 높고 당분은 쌀의 $81.6 \%$ 에 비해 보리는 $7.7 \%$ 로 거의 없다. 섬유질은 쌀의 16 배로 많은 양의 식이섬유를 함유하고 있다(7). 따라서 당뇨병, 뇌졸증, 고혈압, 변비, 비만증 등 성인병을 예방할 수 있는 무공해 건강식품으로 인기가 높은 주곡이다.

막걸리는 전분질 원료(8,9)와 누룩 종류(10), 효모의 종류 (11)에 따라 독특한 풍미가 결정된다. 많은 연구자들은 막걸 리의 품질과 표준화를 위하여 우수한 특성을 가진 종균 개발에 노력하고 있다. 이와 더불어 본 연구에서는 농촌진 흥청 발효가공식품과에서 개발한 토착 발효종균 (Aspergillus oryzae 75-2와 Aspergillus luchuensis 74-5)을 이용하여 발효제(12)를 제조하고 보리 막걸리 제조에 사용 할 효모는 본 연구실에서 확보한 알코올 생성능이 우수하고 풍미가 풍부한 Saccharomyces cerevisiae Y204를 이용하여 보리 막걸리의 품질 특성을 조사하였다. 본 연구는 시판 막걸리의 원료 다양성과 주질을 개선하기 위한 기초자료로 서 막걸리의 품질 고급화에 기여하고자 하였다.

\section{재료 및 방법}

\section{실험재료, 균주 및 시약}

본 연구에 사용된 잡곡류인 보리는 흰찰쌀보리 (Huinchalssal-bori, Gunsan, Korea)를 구입하여 사용하였고, 발효제인 쌀누룩은 국립농업과학원 발효가공식품과에서 보관한 산 생성능이 우수한 Aspergillus luchuensis 74-5(AL, KACC No. 93235P)와 우수한 액화효소의 기능을 가진 $A$ oryzae 75-2(AO, KACC No. 93236P) 종균을 Malto extract agar(MEA, Beton, Dickinson and company(BD), Sparks, MD, USA) 배지에 계대배양한 후, $4^{\circ} \mathrm{C}$ 에 보관하면서 사용하였 다. 효모는 본 연구실에서 강원도 평창군의 전통 발효식품 들로부터 분리한 알코올 생성능이 우수하고 풍부한 풍미를 자아내는 Saccharomyces cerevisiae Y204(KACC No. 93237P) 건조효모를 사용하였고 대조구로는 유럽에서 수 입하여 국내 양조산업에 많이 사용하는 Saccharomyces cerevisiae Fermivin(Lallemand, Denmark) 건조효모를 사용 하였다(13). 분석용 시약(Sigma-Aldrich Co., MO, USA)은 특급을 사용하였다.

\section{보리 막걸리 제조를 위한 알코올 발효조건}

곰팡이 종균별 제조한 쌀누룩(AL nuruk과 $\mathrm{AO}$ nuruk)(12)
과 효모(Y204)를 이용하여 보리 막걸리를 제조하였다. 밑 술은 각각의 종균별 쌀누룩 $300 \mathrm{~g}$ 에 탕수한 담금수를 600 $\mathrm{mL}$ (가수량 $200 \%$ )를 넣고 건조효모 종균 Y204를 0.01\% 넣어 2 일간 발효시켜 밑술로 사용하였다. 제조한 밑술의 술덧 전량에 고두밥(흰찰쌀보리) $300 \mathrm{~g}$ 과 담금수 $600 \mathrm{~mL}$ 를 넣어 보리 막걸리를 제조하였다. 이때 발효 온도별 $(15,20$ 및 $25^{\circ} \mathrm{C}$ )로 나누어서 8 일간 막걸리 발효를 진행하였다. 발 효과정 중 2 일 간격으로 각각의 보리 막걸리 시료를 채취하 여 이화학적 특성과 유기산 및 당류분석들을 수행하였다.

\section{보리 막걸리의 $\mathrm{pH}$, 적정산도 및 아미노산도 특성}

발효 중인 보리 막걸리 술덧의 품질 특성을 규명하기 위해, $\mathrm{pH}$ 는 시료 $30 \mathrm{~mL}$ 를 취하여 $\mathrm{pH}$ meter (Orion $3 \mathrm{star}$, Thremo scientific Co. MA, USA)로 측정하였다. 보리 막걸 리의 적정산도 측정은 막걸리 시료 $15 \mathrm{~mL}$ 를 취하여 여과지 로 여과한 검체 $10 \mathrm{~mL}$ 를 $100 \mathrm{~mL}$ 삼각 플라스크에 취한 다음, $0.5 \%$ phenolphthalein(Sigma-Aldrich, San Fransisco, CA, USA) 지시약을 2-3방울 떨어뜨리고 $0.1 \mathrm{~N}-\mathrm{NaOH}$ 로 적정될 때까지 중화 적정하였으며 소비된 $\mathrm{NaOH}$ 양에 0.009 를 곱하여 lactic acid의 양으로 환산하여 막걸리 시료 중의 총산을 측정하였다(14). 아미노산도는 여과지로 여과한 검 체 $10 \mathrm{~mL}$ 에 $0.5 \%$ phenolphthalein 지시약을 2-3방울 떨어뜨 린 후, $0.1 \mathrm{~N}-\mathrm{NaOH}$ 로 적정한 다음, 여기에 중성포르말린 용액 $5 \mathrm{~mL}$ 을 가하여 유리된 산을 $0.1 \mathrm{~N}-\mathrm{NaOH}$ 로 적정하여 담홍색이 될 때까지 소비된 $0.1 \mathrm{~N}-\mathrm{NaOH}$ 의 $\mathrm{mL}$ 수로 표시하 였다(15).

\section{당도 측정}

보리 막걸리 술덧의 당도는 당도계(T400321 model, Atago Co., Tokyo, Japan)을 사용하였고, 당도는 보리 막걸 리 술덧을 $8,000 \mathrm{rpm}$ 에서 15 분 원심분리(KUBOTA 6200 , Kubota Co., Ltd., Tokyo, Japan)한 상등액을 사용하였다.

\section{막걸리의 알코올 함량}

발효 술덧 내의 알코올 함량은 막걸리 술덧을 부직포로 조여과하여 얻어진 여액 $100 \mathrm{~mL}$ 에 증류수 $100 \mathrm{~mL}$ 를 넣어 혼합한 후 증류하였다. 증류액을 약 $80 \mathrm{~mL}$ 받은 후, 증류수 를 넣어 $100 \mathrm{~mL}$ 로 정용하고 증류액의 온도를 $15^{\circ} \mathrm{C}$ 로 보정 한 다음 주정계(NTS Liquots Licence Aid Center, Seoul, Korea)를 이용하여 측정하였다.

\section{유기산 분석}

각각의 술덧 $10 \mathrm{~mL}$ 을 취하여 $0.2 \mu \mathrm{m}$ membrane filter (Millipore Co., Cork, Ireland)로 여과한 후, 유기산을 분석하 였으며 HPLC(LC-20A Prominence, Shimadzu Co., Kyoto, Japan)을 사용하고, 칼럼은 TSK gel ODS-100V $5 \mu \mathrm{M}$ (4.6×25 cm, TOSOH Co., Nanyo, Japan), 이동상은 $8 \mathrm{mM}$ 
perchloric acid를 사용하였으며 유량은 $1.0 \mathrm{~mL} / \mathrm{min}$, 주입량 은 $10 \mu \mathrm{L}$, 측정은 $\mathrm{UV}(440 \mathrm{~nm})$ 를 사용하여 보리 막걸리의 유기산을 분석하였다.

\section{전자코에 의한 다중향기패턴 분석}

제조한 보리 막걸리의 다중 향기성분 분석은 $0.5 \mathrm{~mL}$ 을 $10 \mathrm{~mL}$ Vial(Ls-Phs-Psck GmbH, Langerwehe, Germany)에 넣고, $40^{\circ} \mathrm{C}$ 에서 30 분간 $500 \mathrm{rpm}$ 으로 교반하여 전자코(Fast GC based HRACLES flash Electronic nose. Alpha Mos, AMcombi PAL, France)를 이용하여 측정하였다. 시료 분석 에는 두 개의 칼럼이 부착된 HRACLES E-nose(DB5 apolar and DB1701 Slightly polar)와 Flame Ionization Detecter(FID)로 검출하였다. 주입량은 Syringe type $(5.0 \mathrm{~mL}$ - $\mathrm{HS}$ )으로 칼럼 온도가 $25^{\circ} \mathrm{C}$ 로 유지된 상태에서 칼럼 헤드 압력 $1.0 \mathrm{psi}$ 로 주입하였다. 분석 시 주입기의 온도는 $200^{\circ} \mathrm{C}$, detector $200^{\circ} \mathrm{C}$ 로 하고 주입기 압력은 $1.0 \mathrm{psi}$, 검출기 압력을 $39.0 \mathrm{psi}$ 로 하였다. 검출된 피크에 따라 차이를 0.900 이상과 RSD $20 \%$ 미만의 sensor를 선택하여 alpha Mos software (version 12.3)를 이용하여 2종류 곰팡이로 제조한 쌀누룩으 로 빚은 보리 막걸리의 서로 다른 온도별 $\left(15,20,25^{\circ} \mathrm{C}\right)$ 에 따른 주성분 분석(Principal Component Analysis, PCA) 패턴 을 조사하였고, 이에 대한 적합도 $\left(\mathrm{R}^{2}\right)$ 와 예측능력 $\left(\mathrm{Q}^{2}\right)$ 은 SPSS statistics(ver. 18.0, SPSS Inc., Chicago, IL, USA)의 판별 분석법(Discriminant Function Analysis)으로 조사하였 다. 시료분석 전 Kovats(Custom Alkanes Blend Standard)를 이용하여 $\mathrm{C}_{6}-\mathrm{C}_{16}$ 까지의 피크 값을 얻어 Standard로 이용하 였다.

\section{통계처리}

통계처리는 SAS(Statistical Analysis System, v7.1, SAS Institute, INC., Cary, NC, USA)에 의한 일원분산분석 (ANOVA)에 의해 검증하였으며, Ducan's multiple range test로 $\mathrm{p}<0.05$ 수준에서 검증하였다.

\section{결과 및 고찰}

\section{발효제별 발효기간에 따른 보리 막걸리의 이화학적 특성}

2 종류 곰팡이로 제조한 쌀누룩을 이용하여 서로 다른 온도조건 $\left(15,20,25^{\circ} \mathrm{C}\right)$ 에서 발효기간별 $(0,2,4,6,8$ 일 $)$ 로 제조한 보리 막걸리의 $\mathrm{pH}$ 변화를 Fig. 1 에 나타내었다. 담금 직후, $\mathrm{pH}$ 는 $\mathrm{AO}$ nuruk을 사용한 술덧(Fig. 1(B))은 $\mathrm{pH}$ 6.4-4.9 로, $\mathrm{AL}$ nuruk을 사용한 술덧(Fig. $1(\mathrm{~A})$ )은 $\mathrm{pH}$ 3.7-3.3으로 큰 차이를 보였다. 이는 쌀누룩에 포함된 $A$ luchuensis 74-5 백국균이 생산한 구연산 때문이라고 생각한다(16). 발효시 간에 따른 $\mathrm{pH}$ 변화는 2 일부터 감소하였다. S. cerevisiae Y204 효모 종균에 의한 $\mathrm{pH}$ 변화는 대조구(Fermivin)와 유의
적인 차이를 나타내지 않았다. 일반적으로 주류의 $\mathrm{pH}$ 는 발효 중 생성되는 다양한 유기산의 영향을 받으며, 발효 및 알코올 변화의 지표로 이용된다(17). 한편 발효 후기에 $\mathrm{pH}$ 가 약간 증가하는 경향을 보이는 것은 효모에 의한 알코 올 발효가 진행되면서 생성된 유기산과 알코올이 반응하여 ester등과 같은 향미성분 형성 등에 이용되므로 $\mathrm{pH}$ 가 증가 하는 것으로 보인다 $(18,19)$.

발효제별 서로 다른 온도조건에서 발효기간에 따른 산도 변화는 $\mathrm{pH}$ 가 감소하는 시점에서 급격히 증가하기 시작하 였다. 산도는 막걸리의 풍미와 보존성에 영향을 주는 중요 한 성분 중의 하나이다(20,21). 곰팡이 종균별 제조한 보리 막걸리의 산도는 담금 직후에 황국균인 $A$ oryzae 75-2(AO nuruk)를 사용한 술덧은 $0.2 \%$ 이고, AO nuruk에 비해 산 생성능이 강한 백국균(AL nuruk)을 사용한 술덧은 $0.8 \%$ 로 큰 차이를 나타내었다 $(\mathrm{p}<0.05)$. AO nuruk를 사용한 술덧의 산도는 2 일째 $0.8 \%$ 급격히 상승하다가 발효 8 일째까지 완 만한 수준을 유지했는데 이는 서로 다른 온도 $\left(15,20,25^{\circ} \mathrm{C}\right)$ 조건에서도 동일하였다. 접종된 효모 $\mathrm{Y} 204$ 와 대조군인 시 판 효모(Fermivin)와는 거의 차이가 없었다. $\mathrm{AL} \mathrm{nuruk}$ 를 사용한 술덧은 발효기간에 따라 산도가 꾸준히 상승하였 고, 발효 $20^{\circ} \mathrm{C}$ 와 $25^{\circ} \mathrm{C}$ 에서는 효모 $\mathrm{Y} 204$ 에 의한 산도가 대조 구(Fermivin)보다 높은 수준으로 상승하였다. 보리 막걸리 에 함유된 산도는 담금 직후에는 원료 중의 유기산이 주로 관여하지만 발효가 점차 진행되면서 젓산이나 효모의 발효 로 생성되는 유기산의 영향으로 인해 산도가 점차 증가된다 는 것은 $\operatorname{Han}$ 등(19)이 보고한 것과 본 연구 결과가 유사하였 다. 이렇게 생성된 유기산이 알코올 등과 반응하여 에스테 르와 같은 향미성분의 형성 등에 이용되면 후기에는 총산 함량이 감소된다는 보고(19)가 있지만 본 연구에서는 그러 한 결과가 도출되지 않았다. 산도가 증가함에 따라 $\mathrm{pH}$ 가 감소(pH 3.64-3.38)되지 않은 것은 술덧의 미생물과 효모의 발효작용으로 단백질과 유기산 등이 분해되어 생성된 아미 노산이 증가되어 완충작용을 했기 때문이라 생각한다(22). 최근, 식약처는 과일 등 유기산을 다량 함유한 원료를 활용 하여 소비자 기호에 맞는 다양한 제품 개발이 가능하도록 탁주(막걸리), 약주, 청주의 총산 규정(식품의 기준 및 규격) 을 폐지하는 개정안을 행정 예고(19.4.30.) 하였다.

발효제별 발효기간에 따른 보리 막걸리의 아미노산도 변화

술의 영양학적 가치뿐만 아니라 술이 가지는 양조학적 특성인 향, 맛, 주질에 기여하는 것이 아미노산이다(23). 아미노산도는 원료에 포함된 단백질이 acidic protease와 기타 peptidase 등의 효소작용에 의해 유리된 아미노산을 측정한 수치로서 분해된 아미노산은 발효 중 효모의 영양원 으로 이용되어 고급 알코올 및 에스테르 등의 향기성분으로 분해되기 때문에 적당량의 유리 아미노산은 주류에 감칠맛 을 부여하여 기호도에 긍정적인 영향을 주지만 지나치게 
아미노산이 많이 생성되면 느끼한 맛을 내어 주질을 떨어뜨 린다(24). 곰팡이 종균을 달리한 2종류 쌀누룩으로 제조한 보리 막걸리의 서로 다른 온도조건에서 발효기간에 따른
아미노산도 변화를 Table 1에 나타내었다. 종균별 제조한 보리 막걸리의 아미노산도는 $\mathrm{AL}$ nuruk과 $\mathrm{AO} n u r u k$ 을 사용 한 술덧에서 효모 $\mathrm{Y} 204$ 의 아미노산도가 $15^{\circ} \mathrm{C}$ 와 $20^{\circ} \mathrm{C}$ 에서
(A)
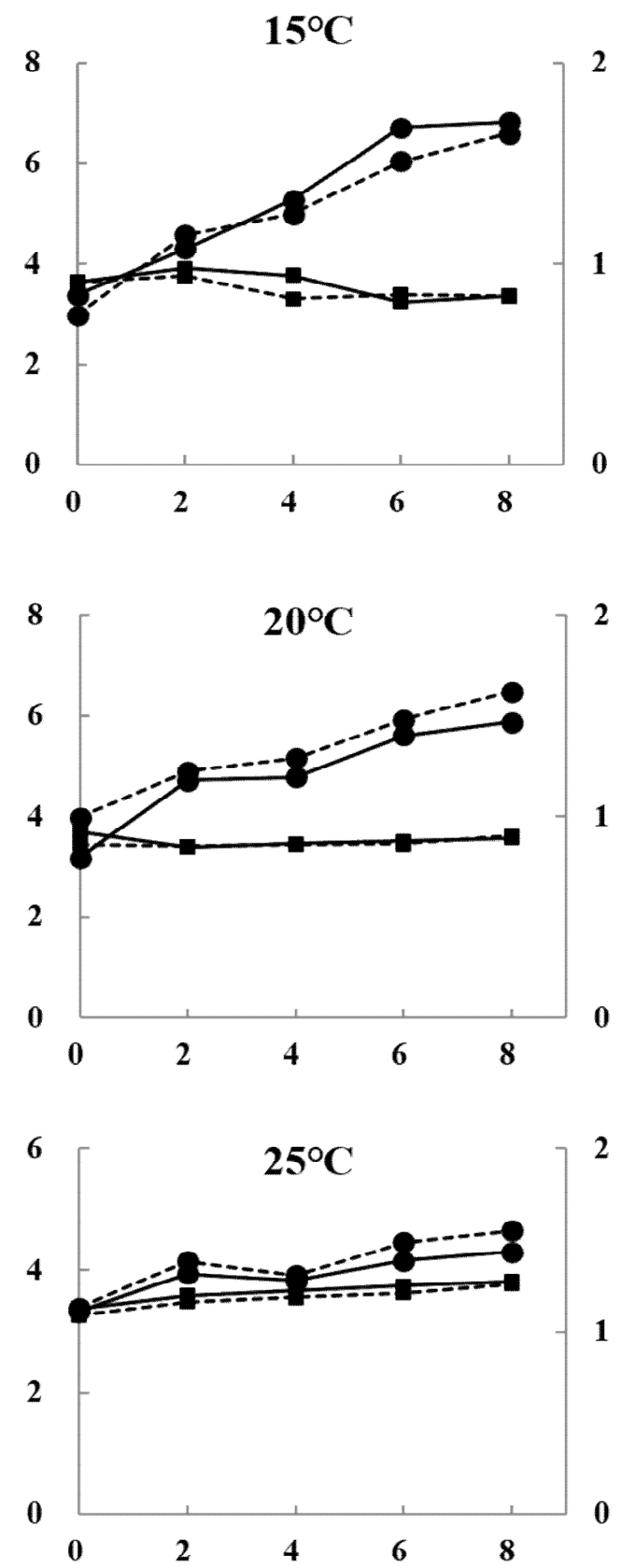

Fermentation periods (day)
(B)

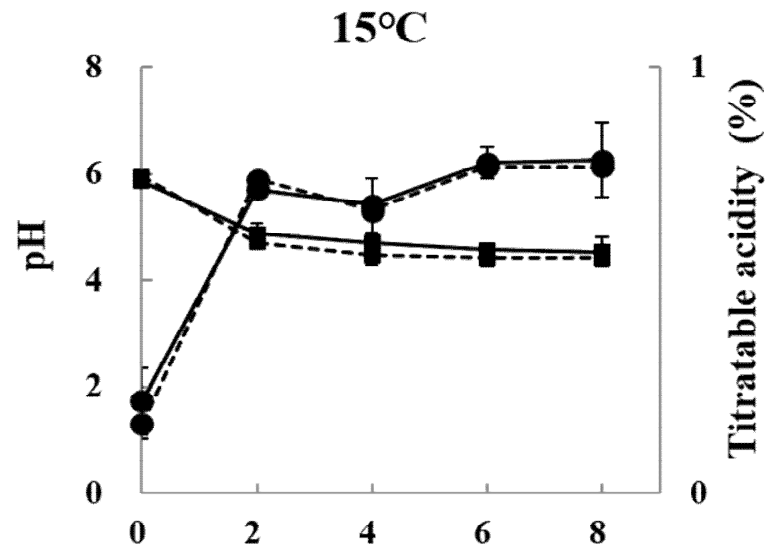

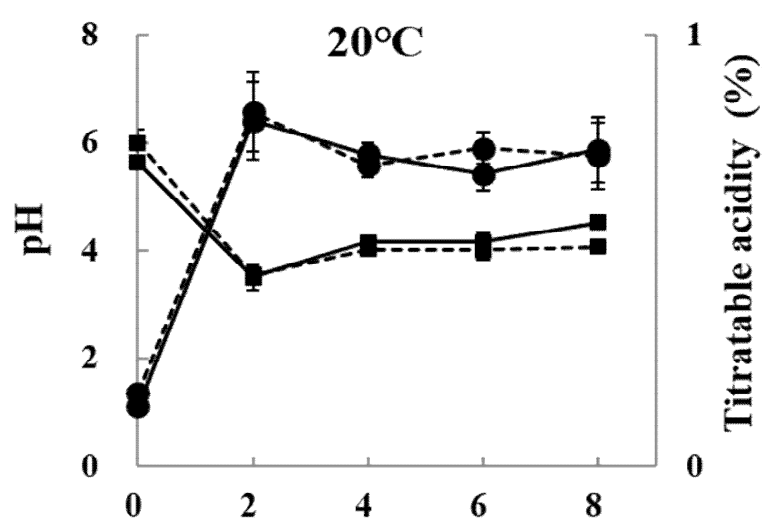

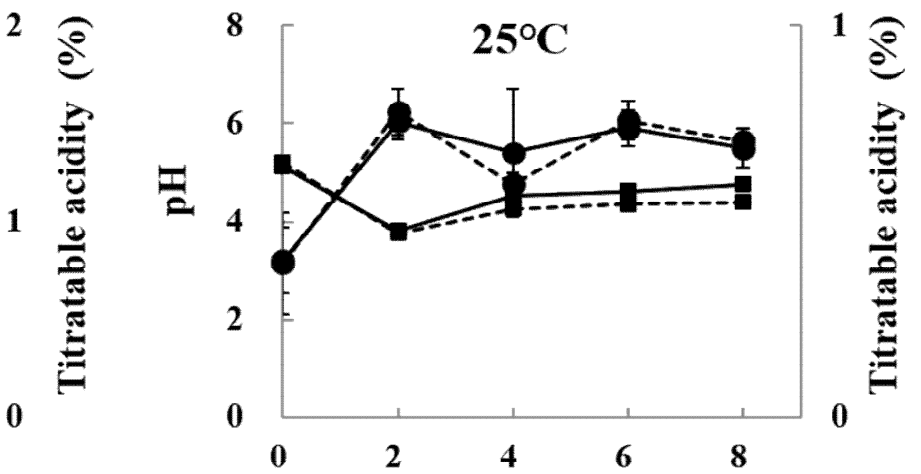

Fermentation periods (day)

Fig. 1. Changes in $\mathrm{pH}$ and titratable acidity of barley-Makgeolli by different fermentation agent nuruk of Y204 according to the various fermentation temperature and period.

(A) shows the $\mathrm{pH}$ and titratable acidity changes of the fermentation agent $\mathrm{AL}$ nuruk (B) shows the $\mathrm{pH}$ and titratable acidity changes of the fermented agent $\mathrm{AO}$ nuruk The straighted lines represent the changes of $\mathrm{pH}$ and titratable acidity for Fermivin. The dashed lines show the changes of $\mathrm{pH}$ and titratable acidity for Y204. Data are presented as the mean for 3 independent experiments. Error bars indicate SD $(\mathrm{p}<0.05)$. $\mathbf{\square}, \mathrm{pH}$; O, Titratable acidity. 
Table 1. Changes in amino acidity of barley-Makgeolli by different fermentation agent nuruk of Y204 according to the fermentation temperature and period

\begin{tabular}{|c|c|c|c|c|c|c|c|}
\hline \multirow{2}{*}{ Fungal nuruk ${ }^{1)}$} & \multirow{2}{*}{$\begin{array}{l}\text { F.T }^{2)} \\
\left({ }^{\circ} \mathrm{C}\right)\end{array}$} & \multirow{2}{*}{ Sample } & \multicolumn{5}{|c|}{ Fermentation periods (day, \%) } \\
\hline & & & 0 & 2 & 4 & 6 & 8 \\
\hline \multirow{6}{*}{$\mathrm{AL}$} & \multirow{2}{*}{15} & Control $^{3)}$ & $0.00 \pm 0.00$ & $1.86 \pm 0.15^{\mathrm{b} 4)}$ & $2.56 \pm 0.50^{\mathrm{a}}$ & $3.07 \pm 0.36^{\mathrm{a}}$ & $3.06 \pm 0.00^{\mathrm{a}}$ \\
\hline & & Y204 & $0.00 \pm 0.00$ & $2.18 \pm 0.60^{\mathrm{a}}$ & $2.26 \pm 0.48^{\mathrm{a}}$ & $2.20 \pm 0.12^{\mathrm{a}}$ & $2.29 \pm 0.26^{\mathrm{a}}$ \\
\hline & \multirow{2}{*}{20} & Control & $0.00 \pm 0.00$ & $1.93 \pm 0.45^{\mathrm{a}}$ & $2.15 \pm 0.07^{\mathrm{a}}$ & $2.51 \pm 0.25^{\mathrm{a}}$ & $2.37 \pm 0.30^{\mathrm{a}}$ \\
\hline & & Y204 & $0.00 \pm 0.00$ & $1.47 \pm 0.03^{\mathrm{c}}$ & $1.85 \pm 0.12^{b}$ & $2.26 \pm 0.09^{\mathrm{a}}$ & $2.15 \pm 0.18^{\mathrm{a}}$ \\
\hline & \multirow{2}{*}{25} & Control & $0.00 \pm 0.00$ & $2.30 \pm 0.43^{\mathrm{b}}$ & $3.30 \pm 0.09^{\mathrm{a}}$ & $3.74 \pm 0.29^{\mathrm{a}}$ & $3.65 \pm 0.57^{\mathrm{a}}$ \\
\hline & & Y204 & $0.00 \pm 0.00$ & $1.55 \pm 0.15^{\mathrm{c}}$ & $2.85 \pm 0.07^{\mathrm{ab}}$ & $3.17 \pm 0.06^{\mathrm{a}}$ & $2.78 \pm 0.31^{\mathrm{b}}$ \\
\hline \multirow{6}{*}{$\mathrm{AO}$} & \multirow{2}{*}{15} & Control & $0.00 \pm 0.00$ & $2.33 \pm 0.32^{a}$ & $2.65 \pm 0.16^{\mathrm{a}}$ & $2.69 \pm 0.47^{\mathrm{a}}$ & $2.68 \pm 0.40^{\mathrm{a}}$ \\
\hline & & Y204 & $0.00 \pm 0.00$ & $1.84 \pm 0.14^{\mathrm{b}}$ & $2.22 \pm 0.29^{\mathrm{ab}}$ & $2.05 \pm 0.22^{\mathrm{b}}$ & $2.77 \pm 0.62^{\mathrm{a}}$ \\
\hline & \multirow{2}{*}{20} & Control & $0.00 \pm 0.00$ & $2.15 \pm 0.67^{\mathrm{b}}$ & $2.03 \pm 0.03^{\mathrm{b}}$ & $2.41 \pm 0.24^{\mathrm{b}}$ & $3.31 \pm 0.26^{\mathrm{a}}$ \\
\hline & & Y204 & $0.00 \pm 0.00$ & $1.93 \pm 0.24^{\mathrm{a}}$ & $1.96 \pm 0.45^{\mathrm{a}}$ & $1.93 \pm 0.45^{\mathrm{a}}$ & $3.03 \pm 1.23^{\mathrm{a}}$ \\
\hline & \multirow{2}{*}{25} & Control & $0.00 \pm 0.00$ & $1.82 \pm 0.18^{\mathrm{d}}$ & $2.50 \pm 0.38^{\mathrm{c}}$ & $3.83 \pm 0.17^{\mathrm{b}}$ & $4.66 \pm 0.51^{\mathrm{a}}$ \\
\hline & & Y204 & $0.00 \pm 0.00$ & $1.53 \pm 0.20^{\mathrm{b}}$ & $1.99 \pm 0.04^{b}$ & $3.18 \pm 0.15^{\mathrm{a}}$ & $3.15 \pm 0.61^{\mathrm{a}}$ \\
\hline
\end{tabular}

${ }^{1)}$ AL: Aspergillus luchuensis 74-5, AO: A. oryzae 75-2

${ }^{2)}$ F.T: fermentation temperature.

${ }^{3}$ Symbols: Control, $S$. cerevisiae Fermivin; Y204, S. cerevisiae Y204

${ }^{4}$ Means with different letters in the same column are significantly different $(\mathrm{p}<0.05)$ by duncan's multiple range test. All values are triplicate determination. Results are shown as mean $\pm \mathrm{SD}$

평균 1.93-2.23\%로 유지되었고 $25^{\circ} \mathrm{C}$ 에서는 평균 2.46$2.59 \%$ 인 반면에 대조구인 Fermivin을 사용한 보리 막걸리 는 발효온도가 낮은 조건 $\left(15^{\circ} \mathrm{C}-20^{\circ} \mathrm{C}\right)$ 에서는 평균 2.24-2.59\%를, 높은 온도 $\left(25^{\circ} \mathrm{C}\right)$ 에서는 평균 3.2-3.25\%로 아 미노산도가 높게 나타났다(Table 1). 일반적으로 발효 초기 (2일)에 급격히 증가한 아미노산도가 $25^{\circ} \mathrm{C}$ 를 제외하고는 발효 종료일까지 완만하게 유지되는 것은 $\operatorname{Im}$ 등(25)이 보고 한 결과와 비슷하다. 아미노산도가 3.0 이하일 때, 주류에 느끼한 맛은 없을 것으로 보고하고 있다(26).

\section{발효제별 발효기간에 따른 보리 막걸리의 당도와 알코올 함량 변화}

2종류 쌀누룩으로 제조한 보리 막걸리의 서로 다른 온도 조건에서 발효기간에 따른 당도 변화를 Fig. 2에 나타내었 다. 술덧 담금 직후 당도를 분석한 결과, 액화효소 기능이 우수한 $\mathrm{AO}$ (Fig. 2(B)) 술덧이 11.73-13.4 ${ }^{\circ} \mathrm{Brix}$ 로 $\mathrm{AL}$ (Fig. 2(A)) 술덧 7.8-10.7 ${ }^{\circ} \mathrm{Brix}$ 보다 유의적으로 높았다. 황국균 인 AO 75-2 보리 막걸리 술덧은 발효 2일째 모든 온도에서 16.67-23.3 ${ }^{\circ} \mathrm{Brix}$ 로 최고의 함량을 나타내었고, 4 일째 급격 히 감소하기 시작했다. 백국균인 AL 74-5 술덧의 당도는 발효 4일째 모든 온도에서 10.57-20.9 ${ }^{\circ} \mathrm{Brix}$ 로 높았으며 발 효 6일째 급격히 감소하였다. 발효기간에 따른 2종류 보리 막걸리의 당도를 분석한 결과, 첨가된 당이 효모에 의해 소비되기 때문에 당의 이용 속도에 차이가 있음을 알 수 있다(27). 대조구인 시판 효모(Fermivin)에 비해 전체적으 로 S. cerevisiae Y204의 당도는 약 1배정도 낮았다. 이
것으로 보아 본 연구에 사용한 Y204 효모는 당 이용 속도가 대조구에 비해 빠르다는 것을 알 수 있었고, 저온 $\left(15^{\circ} \mathrm{C}\right)$ 보다 는 좀 더 높은 중온 $\left(25^{\circ} \mathrm{C}\right)$ 에서 당 이용 속도가 빠르다는 것을 알 수 있다. 종균별 제조한 쌀누룩으로 빚은 보리 막걸 리의 당도 변화는 발효 2 일까지 증가하다가 이후에 급격히 감소하는 것은 $\mathrm{Kim}$ 등(21)의 연구 보고와 일치하였다. 또한 Jin 등(18)의 보고한 당화 amylase 작용으로 원료의 전분질 은 당분으로 분해되고 동시에 효모의 영양원이나 발효기질 로 이용되므로 발효 후기에는 당도가 감소되는 것을 알 수 있다.

한편, 본 연구 결과 당 함량이 급격하게 감소하는 발효 4일째 이후, 술덧의 알코올 함량이 가장 크게 증가했다(Fig. 2). 막걸리의 주질을 결정하는 중요한 요소 중 하나가 효모 의 알코올 생성능이다. 알코올 발효는 당분을 에탄올과 $\mathrm{CO}_{2}$ 로 분해한 것으로 담금 후 기포 발생의 유무로 알코올 발효 가 진행되고 있음을 알 수 있다(20,21). 발효제별 서로 다른 온도조건에 따른 발효기간별의 보리 막걸리 술덧의 알코올 함량 변화는 Fig. 2 에 나타내었다. 저온인 $15^{\circ} \mathrm{C}$ 에서 $\mathrm{AL}$ (Fig. 2(A)) 술덧의 효모 Y204의 발효에 의한 알코올이 $13.2 \%$ 로 $\mathrm{AO}(\mathrm{Fig} .2(\mathrm{~B}))$ 술덧의 알코올 $11.3 \%$ 보다 약 1.2 배 생성능이 높았다. $20^{\circ} \mathrm{C}$ 의 경우, $\mathrm{AL}$ 술덧 $(14.37 \%)$ 보다 $\mathrm{AO}$ 술덧 (15.13\%)의 알코올 발효가 유의적으로 높았고 $25^{\circ} \mathrm{C}$ 에서 발 효한 2종류의 보리 막걸리는 15-16\% 알코올을 생산하지만 대조구와 뚜렷한 차이는 보이지 않았다. 따라서 저온보다 는 발효온도가 높을수록 알코올 발효가 빨리 진행되었으 며, 사용한 S. cerevisiae $\mathrm{Y} 204$ 는 백국(AL)과 황국(AO)의 
(A)
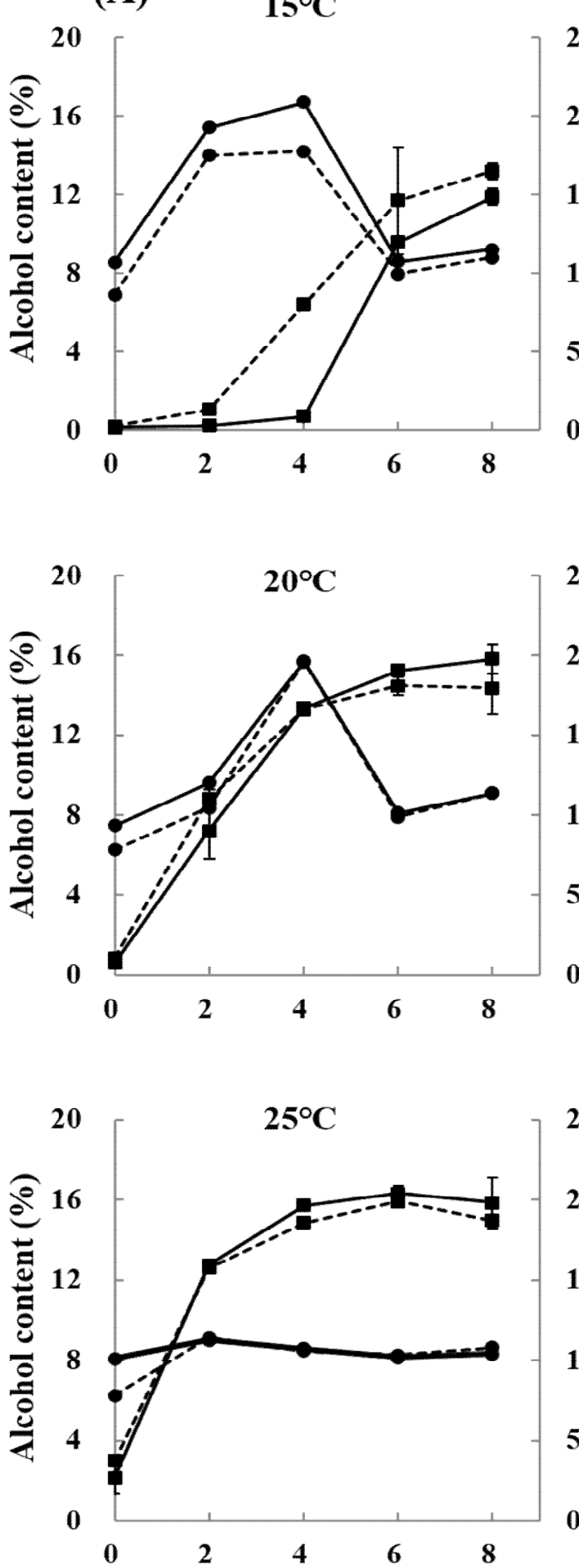

Fermentation periods(day)

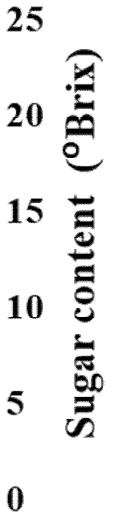

(B)

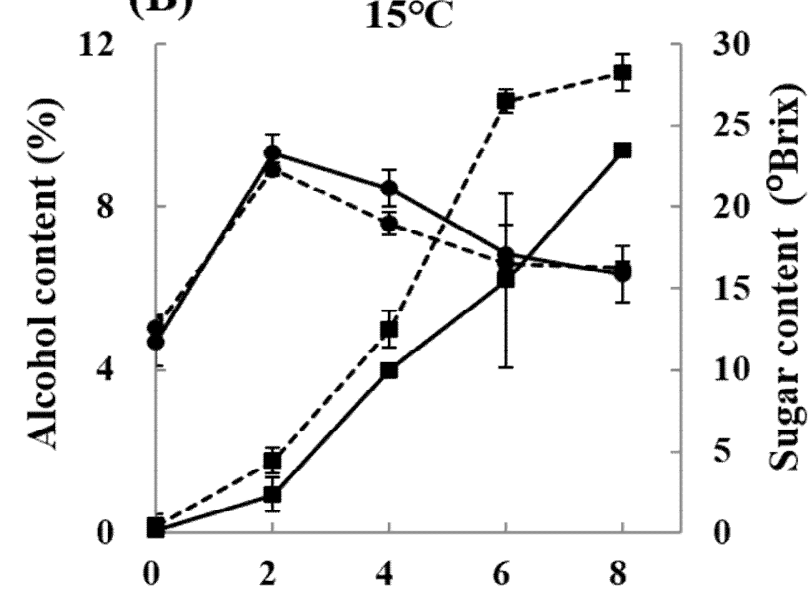

25

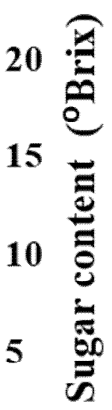

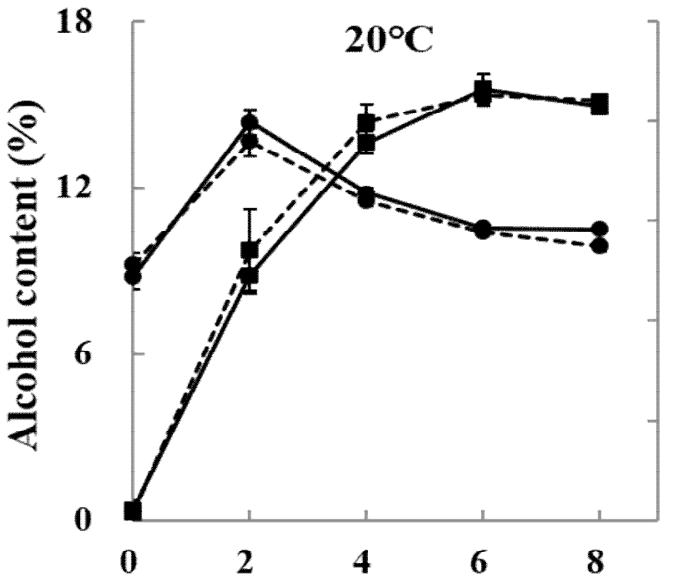

25

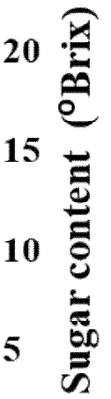

0
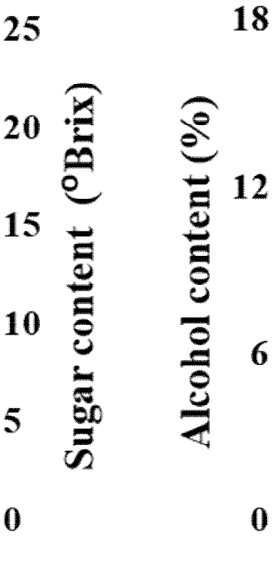

25

20 葛

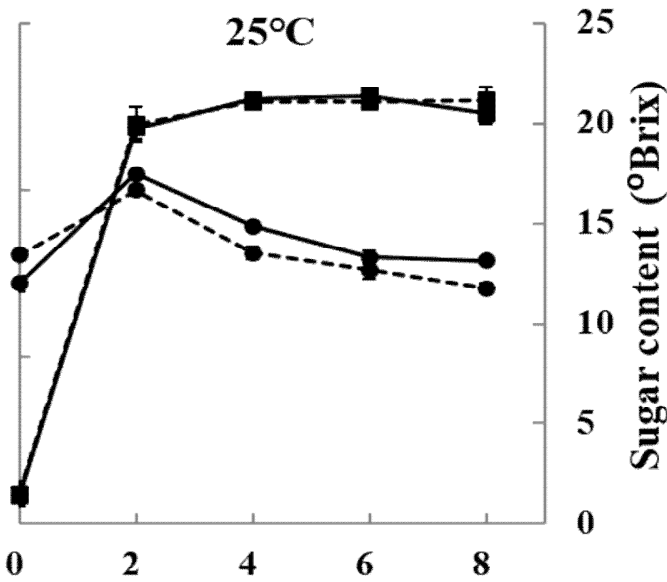

Fermentation periods(day)

Fig. 2. Changes in contents of alcohol and sugar of barley-Makgeolli by different fermented agent nuruk of Y204 according to the various fermentation temperature and period.

(A) shows the alcohol and sugar content changes of the fermentation agent AL nuruk (B) shows the alcohol and sugar content changes of the fermentation agent AO nuruk The straighted lines represent the changes of alcohol and sugar content for Fermivin. The dashed lines show the changes of alcohol and sugar content for Y204. Data are presented as the mean for 3 independent experiments. Error bars indicate SD ( $<<0.05)$. $\square$, Alcohol content; O, Sugar content. 
Table 2. The content of or ganic acids in barley-Makgeolli by fermented agent AL nuruk of Y204 according to the various fermentation temperature and period

\begin{tabular}{|c|c|c|c|c|c|c|c|}
\hline \multirow{2}{*}{$\begin{array}{l}\text { F. }{ }^{1)} \\
\left({ }^{\circ} \mathrm{C}\right)\end{array}$} & \multirow{2}{*}{ Yeast $^{2)}$} & \multirow{2}{*}{ Organic acid } & \multicolumn{5}{|c|}{ Fermentation period (day, $\mathrm{mg} / 100 \mathrm{~mL}$ ) } \\
\hline & & & 0 & 2 & 4 & 6 & 8 \\
\hline \multirow{16}{*}{15} & \multirow{8}{*}{ Control } & Malic acid & $8.19 \pm 0.84^{\mathrm{e3})}$ & $22.42 \pm 0.84^{\mathrm{d}}$ & $46.69 \pm 0.89^{c}$ & $80.17 \pm 0.89^{\mathrm{a}}$ & $59.62 \pm 0.69^{\mathrm{b}}$ \\
\hline & & Lactic acid & n. $d^{4)}$ & n.d & $10.89 \pm 1.11^{\mathrm{c}}$ & $38.00 \pm 0.28^{\mathrm{a}}$ & $25.57 \pm 0.79^{b}$ \\
\hline & & Acetic acid & $1.44 \pm 0.15^{\mathrm{d}}$ & $9.47 \pm 0.09^{c}$ & $9.33 \pm 0.14^{c}$ & $31.23 \pm 0.89^{\mathrm{a}}$ & $20.15 \pm 0.86^{\mathrm{b}}$ \\
\hline & & Citric acid & $132.17 \pm 1.05^{\mathrm{e}}$ & $294.16 \pm 1.05^{\mathrm{b}}$ & $240.76 \pm 1.07^{\mathrm{d}}$ & $493.01 \pm 1.00^{\mathrm{e}}$ & $253.07 \pm 1.23^{\mathrm{c}}$ \\
\hline & & Succinic acid & n.d & $3.90 \pm 0.21^{\mathfrak{c}}$ & n.d & $59.44 \pm 0.77^{\mathrm{a}}$ & $34.28 \pm 0.73^{\mathrm{b}}$ \\
\hline & & Fumaric acid & n.d & $2.74 \pm 0.40^{\mathrm{a}}$ & $2.19 \pm 0.30^{b}$ & n.d & $2.39 \pm 0.41^{\mathrm{ab}}$ \\
\hline & & Propionic acid & $2.32 \pm 0.43^{\mathrm{c}}$ & $12.78 \pm 0.56^{\mathrm{a}}$ & $9.10 \pm 0.69^{b}$ & n.d & $3.09 \pm 0.12^{\mathrm{c}}$ \\
\hline & & Total & 144.12 & 345.47 & 318.95 & 701.85 & 398.16 \\
\hline & \multirow{8}{*}{ Y204 } & Malic acid & $8.38 \pm 0.75^{\mathrm{e}}$ & $27.20 \pm 0.39^{c}$ & $33.69 \pm 0.95^{\mathrm{b}}$ & $24.59 \pm 1.09^{\mathrm{d}}$ & $71.28 \pm 0.76^{\mathrm{a}}$ \\
\hline & & Lactic acid & n.d & $3.98 \pm 0.15^{\mathrm{d}}$ & $15.95 \pm 0.75^{\mathrm{c}}$ & $17.31 \pm 0.90^{b}$ & $56.54 \pm 0.85^{\mathrm{a}}$ \\
\hline & & Acetic acid & $1.01 \pm 0.12^{\mathrm{d}}$ & $17.65 \pm 0.91^{b}$ & $1.31 \pm 0.12^{\mathrm{d}}$ & $15.24 \pm 0.35^{\mathrm{c}}$ & $59.81 \pm 1.00^{\mathrm{a}}$ \\
\hline & & Citric acid & $129.07 \pm 0.12^{\mathrm{e}}$ & $392.43 \pm 1.42^{\mathrm{a}}$ & $348.79 \pm 1.10^{b}$ & $253.75 \pm 1.04^{d}$ & $293.70 \pm 0.89^{c}$ \\
\hline & & Succinic acid & n.d & $3.39 \pm 0.16^{\mathrm{d}}$ & $21.12 \pm 0.89^{b}$ & $14.87 \pm 0.18^{c}$ & $33.36 \pm 0.88^{\mathrm{a}}$ \\
\hline & & Fumaric acid & n.d & $3.22 \pm 0.23^{\mathrm{a}}$ & n.d & n.d & $1.83 \pm 0.73^{b}$ \\
\hline & & Propionic acid & $3.18 \pm 0.31^{b}$ & $11.59 \pm 0.76^{\mathrm{a}}$ & n.d & n.d & $1.16 \pm 1.05^{\mathrm{c}}$ \\
\hline & & Total & 141.63 & 459.46 & 420.87 & 325.75 & 517.67 \\
\hline \multirow{16}{*}{20} & \multirow{8}{*}{ Control } & Malic acid & $7.29 \pm 0.36^{\mathrm{e}}$ & $70.61 \pm 0.94^{\mathrm{a}}$ & $25.06 \pm 1.21^{\mathrm{d}}$ & $50.93 \pm 0.97^{b}$ & $47.66 \pm 0.96^{\mathrm{c}}$ \\
\hline & & Lactic acid & n.d & $31.41 \pm 0.90^{b}$ & $19.03 \pm 0.98^{c}$ & $40.93 \pm 0.96^{\mathrm{a}}$ & $42.02 \pm 0.99^{\mathrm{a}}$ \\
\hline & & Acetic acid & $2.72 \pm 0.17^{\mathrm{d}}$ & $18.90 \pm 0.79^{c}$ & n.d & $27.87 \pm 1.04^{b}$ & $36.93 \pm 1.04^{\mathrm{a}}$ \\
\hline & & Citric acid & $99.64 \pm 0.93^{\mathrm{e}}$ & $331.08 \pm 1.01^{\mathrm{b}}$ & $337.29 \pm 1.06^{\mathrm{a}}$ & $280.97 \pm 0.96^{c}$ & $263.38 \pm 0.85^{\mathrm{d}}$ \\
\hline & & Succinic acid & n.d & $27.35 \pm 0.91^{b}$ & $27.25 \pm 1.10^{b}$ & $48.31 \pm 1.10^{\mathrm{a}}$ & $4.03 \pm 0.18^{\mathrm{c}}$ \\
\hline & & Fumaric acid & n.d & $2.26 \pm 0.37^{\mathrm{a}}$ & n.d & n.d & $1.52 \pm 0.51^{b}$ \\
\hline & & Propionic acid & $1.49 \pm 0.48^{\mathrm{bc}}$ & $5.66 \pm 0.68^{\mathrm{a}}$ & n.d & $2.35 \pm 0.67^{b}$ & $0.94 \pm 0.82^{\mathrm{cd}}$ \\
\hline & & Total & 111.14 & 487.27 & 408.63 & 451.36 & 396.48 \\
\hline & \multirow{8}{*}{ Y204 } & Malic acid & $7.42 \pm 0.57^{\circ}$ & $59.47 \pm 0.68^{b}$ & $41.37 \pm 1.08^{d}$ & $67.66 \pm 0.40^{\mathrm{a}}$ & $53.14 \pm 1.13^{\mathrm{c}}$ \\
\hline & & Lactic acid & $1.30 \pm 0.01^{\mathrm{e}}$ & $35.32 \pm 0.93^{\mathrm{d}}$ & $46.40 \pm 0.79^{\mathrm{a}}$ & $41.56 \pm 1.00^{b}$ & $37.18 \pm 0.84^{c}$ \\
\hline & & Acetic acid & $5.20 \pm 0.31^{\mathrm{d}}$ & $9.30 \pm 0.18^{c}$ & n.d & $50.90 \pm 0.56^{\mathrm{b}}$ & $61.34 \pm 1.11^{\mathrm{a}}$ \\
\hline & & Citric acid & $114.08 \pm 0.96^{\mathrm{e}}$ & $313.35 \pm 0.94^{c}$ & $349.77 \pm 1.01^{\mathrm{b}}$ & $396.11 \pm 1.18^{\mathrm{a}}$ & $244.46 \pm 1.23^{\mathrm{d}}$ \\
\hline & & Succinic acid & $1.44 \pm 0.09^{c}$ & $17.89 \pm 0.88^{b}$ & $20.83 \pm 0.95^{\mathrm{a}}$ & $0.27 \pm 0.12^{\mathrm{d}}$ & $1.29 \pm 0.16^{\mathrm{cd}}$ \\
\hline & & Fumaric acid & n.d & $2.47 \pm 0.42^{\mathrm{a}}$ & n.d & $2.28 \pm 0.50^{\mathrm{a}}$ & $2.21 \pm 0.43^{\mathrm{a}}$ \\
\hline & & Propionic acid & $2.57 \pm 0.59^{d}$ & $4.95 \pm 1.04^{c}$ & n.d & $6.78 \pm 0.78^{b}$ & $8.66 \pm 0.55^{\mathrm{a}}$ \\
\hline & & Total & 132.01 & 442.74 & 458.37 & 565.55 & 408.28 \\
\hline \multirow{16}{*}{25} & \multirow{8}{*}{ Control } & Malic acid & $17.06 \pm 0.29^{e}$ & $52.71 \pm 0.76^{c}$ & $64.56 \pm 0.67^{b}$ & $78.20 \pm 0.47^{\mathrm{a}}$ & $40.61 \pm 0.81^{d}$ \\
\hline & & Lactic acid & n.d & $27.93 \pm 0.99^{c}$ & $38.37 \pm 1.06^{b}$ & $53.37 \pm 0.88^{\mathrm{a}}$ & $38.87 \pm 1.01^{b}$ \\
\hline & & Acetic acid & $4.28 \pm 0.50^{c}$ & n.d & n.d & $40.46 \pm 0.92^{\mathrm{a}}$ & $30.38 \pm 0.64^{\mathrm{b}}$ \\
\hline & & Citric acid & $239.96 \pm 0.98^{d}$ & $282.84 \pm 0.91^{\mathrm{c}}$ & $316.80 \pm 1.11^{\mathrm{b}}$ & $319.82 \pm 1.01^{\mathrm{a}}$ & $237.82 \pm 1.07^{\mathrm{e}}$ \\
\hline & & Succinic acid & $0.62 \pm 0.14^{c}$ & $28.11 \pm 0.99^{b}$ & n.d & n.d & $53.50 \pm 0.78^{\mathrm{a}}$ \\
\hline & & Fumaric acid & $1.75 \pm 0.41^{\mathrm{a}}$ & $2.32 \pm 0.51^{\mathrm{a}}$ & $2.34 \pm 0.45^{\mathrm{a}}$ & $1.83 \pm 0.72^{\mathrm{a}}$ & $2.02 \pm 0.69^{\mathrm{a}}$ \\
\hline & & Propionic acid & $6.53 \pm 0.48^{b}$ & $5.00 \pm 0.81^{c}$ & $4.64 \pm 0.75^{c}$ & $5.23 \pm 0.34^{c}$ & $16.15 \pm 0.86^{\mathrm{a}}$ \\
\hline & & Total & 270.20 & 398.91 & 426.72 & 498.90 & 419.34 \\
\hline & \multirow{8}{*}{ Y204 } & Malic acid & $33.24 \pm 0.74^{\mathrm{d}}$ & $54.81 \pm 0.88^{b}$ & $87.83 \pm 0.89^{\mathrm{a}}$ & $89.20 \pm 1.09^{\mathrm{a}}$ & $42.92 \pm 1.04^{c}$ \\
\hline & & Lactic acid & $10.07 \pm 1.06^{e}$ & $53.51 \pm 0.62^{c}$ & $109.85 \pm 1.05^{\mathrm{a}}$ & $106.66 \pm 0.77^{\mathrm{b}}$ & $37.27 \pm 0.93^{\mathrm{d}}$ \\
\hline & & Acetic acid & $28.27 \pm 0.35^{b}$ & n.d & n.d & $29.02 \pm 0.54^{b}$ & $67.06 \pm 0.61^{\mathrm{a}}$ \\
\hline & & Citric acid & $275.67 \pm 0.92^{\mathrm{d}}$ & $288.65 \pm 5.07^{\mathrm{c}}$ & $384.48 \pm 1.01^{\mathrm{a}}$ & $346.23 \pm 6.18^{b}$ & $245.68 \pm 0.79^{e}$ \\
\hline & & Succinic acid & n.d & $23.50 \pm 0.69^{b}$ & $1.15 \pm 0.14^{\mathrm{d}}$ & $4.00 \pm 0.81^{\mathrm{c}}$ & $47.54 \pm 0.76^{\mathrm{a}}$ \\
\hline & & Fumaric acid & $1.65 \pm 0.24^{b}$ & $2.62 \pm 0.09^{\mathrm{a}}$ & $1.88 \pm 0.51^{\mathrm{ab}}$ & $1.85 \pm 0.54^{\mathrm{ab}}$ & $1.90 \pm 0.59^{\mathrm{ab}}$ \\
\hline & & Propionic acid & $6.92 \pm 0.42^{\mathrm{a}}$ & $3.08 \pm 0.41^{\mathrm{c}}$ & $7.61 \pm 0.80^{\mathrm{a}}$ & $7.72 \pm 0.71^{\mathrm{a}}$ & $5.44 \pm 0.57^{b}$ \\
\hline & & Total & 355.83 & 426.17 & 592.80 & 584.68 & 447.80 \\
\hline
\end{tabular}

${ }^{1)}$ F.T: Fermentation temperature

${ }^{2)}$ Control: Saccharomyces cerevisiae Fermivin, Y204: S. cerevisiae Y204

${ }^{3)}$ Means with different letters in the same row are significantly different $(p<0.05)$ by ducan's multiple range test.

${ }^{4)}$ Not detected 
Table 3. The content of organic acids in barley-Makgeolli by fermented agent AO nuruk of Y204 according to the various fermentation temperature and period

\begin{tabular}{|c|c|c|c|c|c|c|c|}
\hline \multirow{2}{*}{$\begin{array}{l}\text { F.T } \\
\left({ }^{1)} \mathrm{C}\right)\end{array}$} & \multirow{2}{*}{ Yeast $^{2)}$} & \multirow{2}{*}{ Organic acid } & \multicolumn{5}{|c|}{ Fermentation period (day, mg/100 mL) } \\
\hline & & & 0 & 2 & 4 & 6 & 8 \\
\hline \multirow{16}{*}{15} & \multirow{8}{*}{ Control } & Malic acid & $6.12 \pm 0.3^{\mathrm{a}}$ & $5.33 \pm 0.45^{b}$ & $3.30 \pm 0.65^{\mathfrak{c}}$ & $4.98 \pm 0.21^{\mathrm{b}}$ & $1.50 \pm 0.11^{\mathrm{d}}$ \\
\hline & & Lactic acid & $1.05 \pm 0.08^{d}$ & $1.57 \pm 0.10^{d}$ & $5.99 \pm 0.02^{\mathrm{c}}$ & $58.95 \pm 1.03^{\mathrm{a}}$ & $22.84 \pm 0.72^{b}$ \\
\hline & & Acetic acid & $3.29 \pm 0.40^{\mathrm{d}}$ & $6.26 \pm 0.37^{\mathrm{c}}$ & $7.10 \pm 0.21^{\mathrm{b}}$ & n.d & $10.64 \pm 0.37^{\mathrm{a}}$ \\
\hline & & Citric acid & $13.11 \pm 0.90^{b}$ & $11.35 \pm 0.66^{c}$ & $8.83 \pm 0.04^{\mathrm{d}}$ & $25.61 \pm 0.98^{\mathrm{a}}$ & $5.75 \pm 0.14^{\mathrm{e}}$ \\
\hline & & Succinic acid & $0.29 \pm 0.06^{\mathrm{e}}$ & $1.32 \pm 0.09^{d}$ & $4.82 \pm 0.71^{\mathrm{c}}$ & $34.34 \pm 0.89^{\mathrm{a}}$ & $10.95 \pm 0.46^{\mathrm{b}}$ \\
\hline & & Fumaric acid & $1.82 \pm 0.49^{\mathrm{a}}$ & $1.66 \pm 0.55^{\mathrm{a}}$ & n.d & $1.72 \pm 0.62^{\mathrm{a}}$ & n.d \\
\hline & & Propionic acid & $1.12 \pm 0.89^{b c}$ & $2.06 \pm 0.61^{b}$ & $2.03 \pm 0.86^{b}$ & $5.01 \pm 0.78^{\mathrm{a}}$ & n.d \\
\hline & & Total & 26.81 & 29.55 & 32.07 & 130.61 & 51.69 \\
\hline & \multirow{8}{*}{ Y204 } & Malic acid & $8.95 \pm 0.22^{\mathrm{a}}$ & $6.06 \pm 0.54^{b}$ & $6.25 \pm 0.40^{b}$ & $10.08 \pm 0.95^{\mathrm{a}}$ & $8.96 \pm 0.73^{\mathrm{a}}$ \\
\hline & & Lactic acid & $1.08 \pm 0.27^{\mathrm{d}}$ & $1.30 \pm 0.21^{\mathrm{d}}$ & $1.98 \pm 0.21^{\mathrm{c}}$ & $4.47 \pm 0.20^{\mathrm{a}}$ & $3.34 \pm 0.39^{b}$ \\
\hline & & Acetic acid & $1.11 \pm 0.50^{\mathrm{d}}$ & $10.74 \pm 0.59^{c}$ & $12.05 \pm 0.52^{c}$ & $20.39 \pm 1.00^{\mathrm{a}}$ & $18.48 \pm 1.03^{\mathrm{b}}$ \\
\hline & & Citric acid & $22.56 \pm 0.78^{\mathrm{a}}$ & $12.24 \pm 0.35^{b}$ & $8.04 \pm 1.12^{d}$ & $11.51 \pm 0.50^{b}$ & $9.11 \pm 0.50^{c}$ \\
\hline & & Succinic acid & $1.55 \pm 0.34^{\mathrm{d}}$ & $0.98 \pm 0.49^{d}$ & $4.55 \pm 0.32^{c}$ & $11.24 \pm 0.90^{\mathrm{a}}$ & $9.17 \pm 0.95^{b}$ \\
\hline & & Fumaric acid & $1.77 \pm 0.43^{\mathrm{b}}$ & $2.54 \pm 0.67^{\mathrm{a}}$ & n.d & n.d & n.d \\
\hline & & Propionic acid & $2.60 \pm 0.41^{\mathrm{a}}$ & $2.04 \pm 0.31^{\mathrm{b}}$ & n.d & n.d & n.d \\
\hline & & Total & 39.61 & 35.89 & 32.88 & 57.69 & 49.06 \\
\hline \multirow{16}{*}{20} & \multirow{8}{*}{ Control } & Malic acid & $7.10 \pm 0.47^{c}$ & $5.77 \pm 0.70^{d}$ & $7.48 \pm 0.52^{\mathrm{c}}$ & $11.01 \pm 0.30^{b}$ & $28.19 \pm 0.39^{a}$ \\
\hline & & Lactic acid & n.d & $3.53 \pm 0.03^{c}$ & $96.53 \pm 0.78^{a}$ & $4.26 \pm 0.26^{c}$ & $19.81 \pm 0.53^{\mathrm{b}}$ \\
\hline & & Acetic acid & $3.62 \pm 0.28^{\mathcal{C}}$ & $2.09 \pm 0.50^{\mathrm{d}}$ & $11.97 \pm 0.98^{\mathrm{a}}$ & $5.11 \pm 0.30^{b}$ & n.d \\
\hline & & Citric acid & $16.32 \pm 0.91^{\mathrm{b}}$ & $8.62 \pm 0.11^{c}$ & $4.61 \pm 0.26^{\mathrm{d}}$ & $4.13 \pm 0.32^{\mathrm{d}}$ & $19.12 \pm 0.41^{\mathrm{a}}$ \\
\hline & & Succinic acid & $2.04 \pm 0.10^{c}$ & $8.78 \pm 0.59^{b}$ & $4.56 \pm 0.45^{\mathrm{d}}$ & $7.00 \pm 0.29^{c}$ & $39.49 \pm 0.80^{\mathrm{a}}$ \\
\hline & & Fumaric acid & $1.97 \pm 0.50^{\mathrm{b}}$ & n.d & n.d & n.d & $2.91 \pm 0.92^{\mathrm{a}}$ \\
\hline & & Propionic acid & $1.27 \pm 0.29^{\mathrm{b}}$ & n.d & n.d & n.d & $2.84 \pm 0.50^{\mathrm{a}}$ \\
\hline & & Total & 32.33 & 28.79 & 125.16 & 31.51 & 112.34 \\
\hline & \multirow{8}{*}{ Y204 } & Malic acid & $11.08 \pm 0.30^{c}$ & $34.63 \pm 0.66^{b}$ & $10.27 \pm 0.86^{c}$ & $48.84 \pm 0.90^{\mathrm{a}}$ & $35.18 \pm 0.84^{b}$ \\
\hline & & Lactic acid & $6.29 \pm 0.51^{\mathrm{d}}$ & $12.15 \pm 0.44^{c}$ & $2.49 \pm 0.35^{\mathrm{e}}$ & $33.41 \pm 0.60^{\mathrm{a}}$ & $24.45 \pm 0.85^{b}$ \\
\hline & & Acetic acid & $2.03 \pm 0.48^{d}$ & n.d & $5.03 \pm 0.27^{\mathrm{b}}$ & $53.82 \pm 0.93^{\mathrm{a}}$ & $3.50 \pm 0.18^{c}$ \\
\hline & & Citric acid & $20.43 \pm 1.04^{b}$ & $8.55 \pm 0.54^{c}$ & $4.53 \pm 0.08^{d}$ & $24.28 \pm 0.52^{\mathrm{a}}$ & $20.96 \pm 1.03^{b}$ \\
\hline & & Succinic acid & $1.27 \pm 0.38^{\mathrm{e}}$ & $8.84 \pm 0.28^{c}$ & $7.63 \pm 0.52^{d}$ & $29.43 \pm 0.58^{a}$ & $22.22 \pm 1.11^{\mathrm{b}}$ \\
\hline & & Fumaric acid & $1.77 \pm 0.54^{\mathrm{b}}$ & n.d & n.d & $2.73 \pm 0.39^{\mathrm{a}}$ & $2.55 \pm 0.54^{\mathrm{a}}$ \\
\hline & & Propionic acid & $1.66 \pm 0.35^{\mathrm{a}}$ & n.d & n.d & $1.37 \pm 0.64^{\mathrm{a}}$ & $1.23 \pm 0.23^{\mathrm{a}}$ \\
\hline & & Total & 44.54 & 64.16 & 29.94 & 193.89 & 110.09 \\
\hline \multirow{16}{*}{25} & \multirow{8}{*}{ Control } & Malic acid & $4.10 \pm 0.10^{d}$ & $19.30 \pm 0.84^{b}$ & $5.36 \pm 0.52^{d}$ & $51.19 \pm 0.96^{\mathrm{a}}$ & $7.94 \pm 1.05^{c}$ \\
\hline & & Lactic acid & $1.76 \pm 0.10^{e}$ & $9.56 \pm 0.11^{b}$ & $2.81 \pm 0.12^{\mathrm{d}}$ & $41.25 \pm 1.05^{\mathrm{a}}$ & $6.11 \pm 0.22^{c}$ \\
\hline & & Acetic acid & $5.66 \pm 0.12^{b}$ & $3.95 \pm 0.39^{c}$ & $1.43 \pm 0.16^{\mathrm{d}}$ & $58.91 \pm 0.60^{\mathrm{a}}$ & $0.74 \pm 0.61^{\mathrm{e}}$ \\
\hline & & Citric acid & $9.68 \pm 0.31^{\mathrm{b}}$ & $9.51 \pm 0.28^{b}$ & $2.27 \pm 0.10^{d}$ & $22.64 \pm 0.86^{\mathrm{a}}$ & $5.98 \pm 0.14^{c}$ \\
\hline & & Succinic acid & $0.93 \pm 0.30^{d}$ & $12.97 \pm 0.99^{\mathrm{a}}$ & $7.61 \pm 0.50^{c}$ & $1.77 \pm 0.54^{\mathrm{c}}$ & $9.09 \pm 0.20^{b}$ \\
\hline & & Fumaric acid & $1.62 \pm 0.51^{b}$ & n.d & n.d & $2.98 \pm 0.61^{\mathrm{a}}$ & n.d \\
\hline & & Propionic acid & $1.53 \pm 0.88^{b}$ & n.d & n.d & $2.53 \pm 0.52^{\mathrm{a}}$ & n.d \\
\hline & & Total & 25.28 & 55.28 & 19.48 & 181.27 & 29.87 \\
\hline & \multirow{8}{*}{ Y204 } & Malic acid & $11.30 \pm 0.52^{c}$ & $15.69 \pm 0.90^{b}$ & $11.68 \pm 0.49^{c}$ & $51.19 \pm 0.98^{\mathrm{a}}$ & $8.98 \pm 1.01^{\mathrm{d}}$ \\
\hline & & Lactic acid & $4.01 \pm 0.11^{\mathrm{d}}$ & $8.45 \pm 0.44^{c}$ & $9.98 \pm 0.42^{b}$ & $41.25 \pm 0.53^{\mathrm{a}}$ & $8.06 \pm 0.39^{c}$ \\
\hline & & Acetic acid & $17.87 \pm 1.04^{b}$ & $8.58 \pm 0.13^{\mathrm{d}}$ & $11.15 \pm 0.17^{c}$ & $58.91 \pm 1.00^{\mathrm{a}}$ & $9.41 \pm 0.04^{d}$ \\
\hline & & Citric acid & $25.38 \pm 1.11^{\mathrm{a}}$ & $6.37 \pm 0.58^{c}$ & $7.34 \pm 0.34^{c}$ & $22.64 \pm 0.93^{b}$ & $6.56 \pm 0.33^{c}$ \\
\hline & & Succinic acid & $5.12 \pm 0.22^{\mathrm{a}}$ & $3.25 \pm 0.09^{b}$ & $5.26 \pm 0.48^{\mathrm{a}}$ & $1.77 \pm 0.62^{\mathrm{c}}$ & $4.70 \pm 0.69^{\mathrm{a}}$ \\
\hline & & Fumaric acid & $2.00 \pm 0.51^{b}$ & n.d & n.d & $2.98 \pm 0.39^{\mathrm{a}}$ & n.d \\
\hline & & Propionic acid & $1.83 \pm 0.18^{b}$ & n.d & n.d & $2.53 \pm 0.48^{\mathrm{a}}$ & n.d \\
\hline & & Total & 67.51 & 42.33 & 45.41 & 181.27 & 37.71 \\
\hline
\end{tabular}

${ }^{1)}$ F.T: Fermentation temperature

${ }^{2)}$ Control: Saccharomyces cerevisiae Fermivin, Y204: S. cerevisiae Y204

${ }^{3)}$ Means with different letters in the same row are significantly different $(p<0.05)$ by ducan's multiple range test.

${ }^{4)}$ Not detected 
어떠한 발효제를 사용하여도 알코올 발효가 잘 진행되는 것을 알 수 있다.

\section{발효제별 발효기간에 따른 보리 막걸리의 유기산 변화}

막걸리 발효에 관여하는 효모와 유산균은 막걸리 술덧으
로 다양한 유기산을 생성(25)하면서 맛과 품질을 결정하는 중요한 역할을 한다(28). 2종류 발효제(AL 74-5과 $\mathrm{AO} 75-2)$ 와 효모로 발효기간 및 온도별 제조한 보리 막걸리의 유기 산을 HPLC로 분석한 결과, malic, lactic, acetic, citric, succinic, fumaric 및 propionic acid로 7종류의 유기산이 확인

(A)

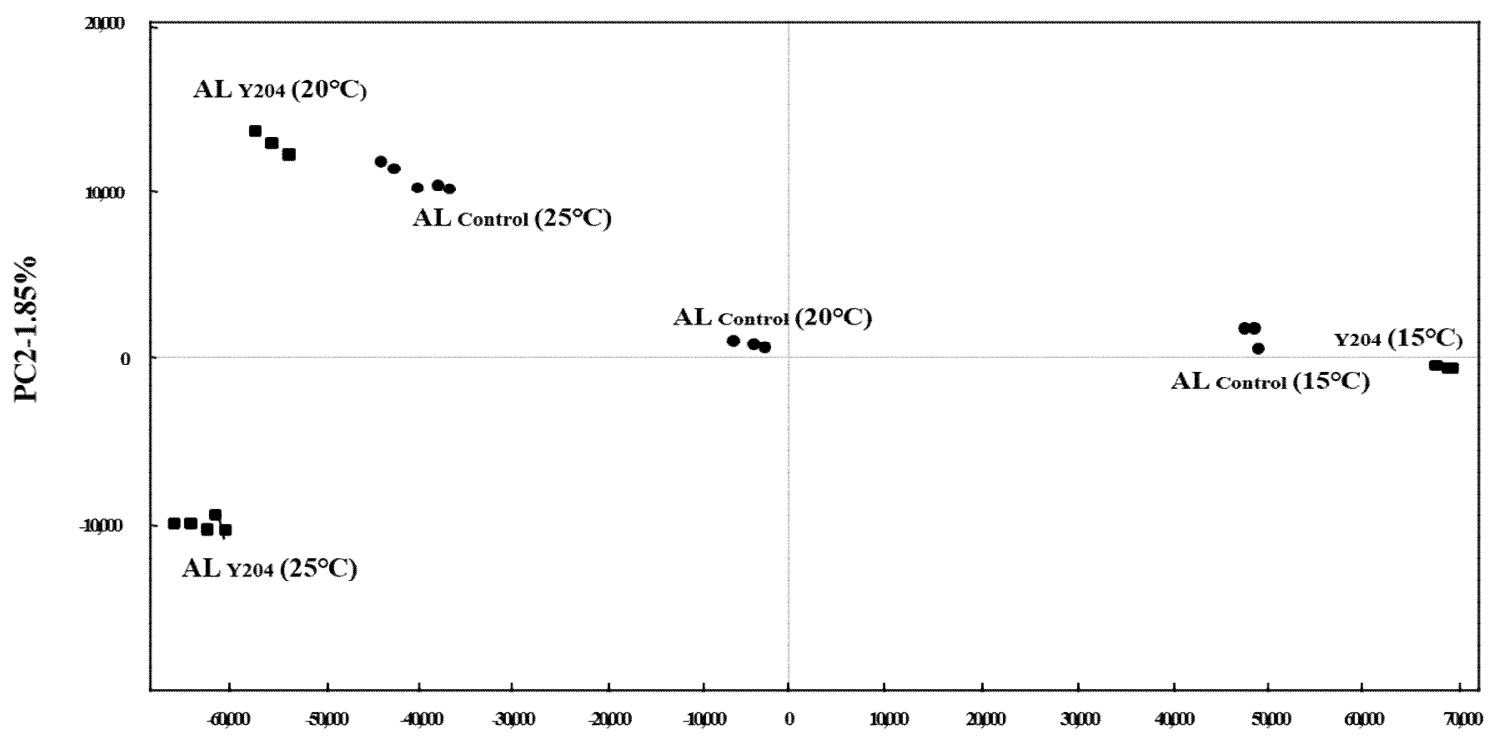

PC1-97.97\%

(B)

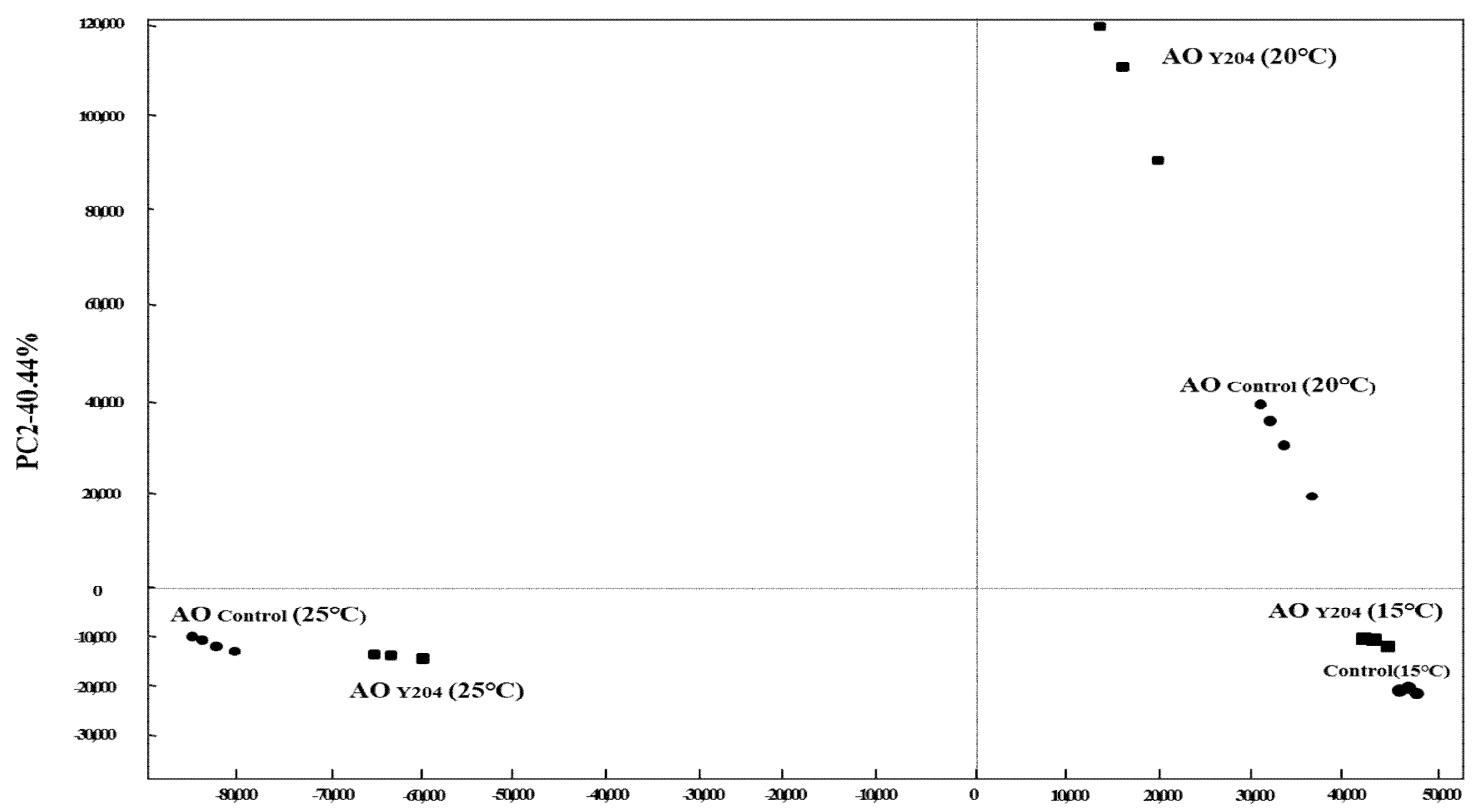

Fig. 3. Principal component analysis of changes in the pattern of multiple volatile components for barley-Makgeolli by electronic nose. (A) shows the analysis of changes by $\mathrm{AL}$ nuruk of Y204 according to the various fermentation temperature. (B) shows the changes by AO nuruk of Y204 according to the various fermentation temperature. $\mathbf{O}$, control (Fermivin); $\mathbf{\square}$, Y204. 
되었다(Table 2와 3). 백국(AL, Table 2)과 황국(AO, Table 3) 발효제에 Y204 효모로 빚은 보리 막걸리와 대조구로 사용한 수입산 Fermivin 효모로 빚은 보리 막걸리는 저온 $\left(15^{\circ} \mathrm{C}\right)$ 에서 $25^{\circ} \mathrm{C}$ 까지 발효온도가 높아질수록 부드러운 신 맛을 내는 malic acid 함량이 증가하는 경향을 나타내었다. 반면에 $\mathrm{AL}$ 로 빚은 보리 막걸리는 높은 발효온도 $\left(25^{\circ} \mathrm{C}\right)$ 보다 저온발효 $\left(15^{\circ} \mathrm{C}\right)$ 에서 막걸리의 맛에 영향을 미치는 citric acid가 다른 유기산보다 많이 검출(129.07-493.01 mg/100 $\mathrm{mL}$ ) 된 반면에 $25^{\circ} \mathrm{C}$ 에서 발효한 막걸리에서 lactic과 acetic acid 함량이 증가하였다. 따라서 황국(AO 75-2) 발효제로 빚은 술덧보다 백국(AL 74-5) 술덧의 유기산 함량이 높았으 며 대조군인 수입산 효모(Control, S. cerevisiae Fermivin)보 다는 국산 효모종균인 S. cerevisiae로 발효한 보리 막걸리의 유기산 함량이 1-1.3배 높게 나타났다(Table 2).

\section{발효제별 발효기간에 따른 보리 막걸리의 향기패턴 분석}

국산 토착 곰팡이 종균(A luchuensis 74-5 및 $A$ oryzae 75-2)으로 제조한 2종류 발효제(AL nuruk 및 $\mathrm{AO}$ nuruk)로 빚은 보리 막걸리의 발효기간 및 온도조건에 따른 다중 향기패턴 분석을 Fig. 3에 나타내었다. $\mathrm{AL}$ nuruk으로 빚은 보리 막걸리의 전자코 주성분 분석(Principal Component Analysis, PCA) 패턴은 Fig. $3 \mathrm{~A}$ 에 나타내었다. 제 1 주성분 값의 기여율(proportion)이 $97.97 \%$ 로 발효온도에 따른 향기 패턴이 $\mathrm{PC} 1$ 의 방향으로 구분되었다. 제 1 주성분의 양의 방 향에 $15^{\circ} \mathrm{C}$ 가 위치했으며, $20^{\circ} \mathrm{C}$ 및 $25^{\circ} \mathrm{C}$ 는 제 1 주성분의 음의 방향에 위치하면서 향기성분 패턴이 집약적이지 않고 넓게 분포하고 있는 것을 볼 수 있다. $\mathrm{AL}$ 종균으로 빚은 보리 막걸리의 서로 다른 온도 그룹들에 대한 $\mathrm{PCA}$ 모델은 $\mathrm{R}^{2}$ 값 이 $0.99, \mathrm{Q}^{2}$ 값이 0.88 로 통계적 유의성을 보였다. 한편, $\mathrm{AO}$ 종균으로 빚은 보리 막걸리의 전자코 PCA 패턴은 Fig. 3B 에 나타내었다. 제 1 주성분 값의 기여율은 $59.24 \%$ 로 각 발효 온도 간의 향기패턴이 $\mathrm{AL}$ 종균으로 빚은 보리 막걸리와는 확연히 다름을 확인하였다. 발효 $20^{\circ} \mathrm{C}$ 는 제 2 주성분 값의 0 과 120,000 사이에 분포하면서 저온인 $15^{\circ} \mathrm{C}$ 와 함께 제 1 주 성분의 양의 방향에 위치했고, $25^{\circ} \mathrm{C}$ 는 제 1 주성분의 음의 방향에 위치했다. $\mathrm{AO}$ 종균으로 빚은 보리 막걸리의 서로 다른 온도 그룹들에 대한 $\mathrm{PCA}$ 모델은 $\mathrm{R}^{2}$ 값이 $0.99, \mathrm{Q}^{2}$ 값이 0.94로 높은 통계적 유의성을 보였다. 발효제(AL nuruk 및 $\mathrm{AO}$ nuruk)를 달리한 국산 효모(Y204)로 빚은 보리 막걸리 의 서로 다른 온도에 따른 PCA 향기성분을 활용한 다양한 막걸리 제품 개발이 가능할 것으로 여겨지며, 추가적으로 보리 막걸리의 향기성분의 종류 등이 규명되어져야 할 것이다.

\section{요 약}

본 연구에서는 알코올 생성능이 우수하고 풍미가 풍부한
S. cerevisiae $\mathrm{Y} 204$ 에 대한 서로 다른 2종류 곰팡이 종균(AO 75-2, AL 74-5)으로 만든 발효제로 발효기간(0-8일) 및 온도 $\left(15,20\right.$ 및 $\left.25^{\circ} \mathrm{C}\right)$ 별로 빚은 보리 막걸리의 품질 특성을 비교 하였다. 황국(AO 75-2)으로 빚은 막걸리의 $\mathrm{pH}$ 는 6.4-4.9로 백국(AL 74-5) 술덧의 $\mathrm{pH}$ 는 3.7-3,3로 사용한 곰팡이 종균 에 따라 큰 차이를 보였다. 제조한 보리 막걸리의 산도를 살펴본 결과, $\mathrm{AO}$ 는 $0.2 \%$ 이고 $\mathrm{AL}$ 은 $0.8 \%$ 로 황국 발효제보 다 백국 발효제로 빚은 막걸리 산도가 4배 높은 것이 확인되 었다. 알코올 발효 2 일부터 급격히 증가한 아미노산도가 $25^{\circ} \mathrm{C}$ 를 제외하고는 발효 종료일까지 완만하게 유지되었으 며 특히, 막걸리 발효온도에 따라 발효제별 사용한 Fermivin 과 S. cerevisiae Y204의 아미노산도 함량의 차이가 뚜렷하 였다. 당도는 $\mathrm{AO}$ 술덧이 $\mathrm{AL}$ 술덧보다 유의적으로 높았으 며 대조구인 Fermivin보다 S. cerevisiae Y204 효모가 술덧에 잔존하는 당 소비가 빨랐다. 황국(AO)과 백국(AL) 발효제 에 Y204 효모종균으로 $25^{\circ} \mathrm{C}$ 에서 발효한 보리 막걸리는 대 조구로 사용한 수입산 과실주 제조용 Fermivin 효모와는 유의적인 차이를 보이지 않았으며 알코올 생산능도 $15-16 \%$ 로 수입산 효모를 대체할 수 있을 것으로 여겨진다. 검출된 유기산은 $15^{\circ} \mathrm{C}$ 에서 $25^{\circ} \mathrm{C}$ 로 발효온도가 높아질수록 malic acid 함량이 증가하는 경향을 보였다. 반면에 저온발 효 $\left(15^{\circ} \mathrm{C}\right)$ 한 $\mathrm{AL}$ 술덧은 다른 유기산보다 citric acid 함량이 가장 높게 나타났다. 보리 막걸리 향기성분 패턴은 $\mathrm{AL}$ $n u r u k$ 과 $\mathrm{AO}$ nuruk 발효제별 온도에 따른 차이가 있어 향기 성분의 다양성을 예측할 수 있었다. 2 종류 곰팡이 종균으로 제조한 발효제(황국, 백국)에 S. cerevisiae Y204로 빚은 보 리 막걸리의 주질 특성을 조사한 것으로 향후, 침체된 국내 막걸리 시장 및 신제품 개발에 도움을 줄 것으로 기대된다.

\section{감사의 글}

이 논문은 농촌진흥청 농업과학기술개발사업(과제번호: PJ01248302)의 지원에 의해 이루어진 것이며, 연구비 지원 에 감사드립니다.

\section{References}

1. Lee TS, Han EH (2001) Volatile flavor components in mash of Takju prepared by using Aspergillus oryzae Nuruks. Korean J Food Sci Technol, 33, 366-372

2. Kim GM, Jung WJ, Shin JH, Kang MJ, Sung NJ (2011) Preparation and quality characteristics of Makgeolli made with black garlic extract and Sulgidduk J Korean Soc Food Sci Nutr, 40, 759-766

3. Woo SM, Shin JS, Seong JH, Yeo SH, Choi JH, Kim 
TY, Jeong YJ (2010) Quality characteristics of brown rice Takju by different Nuruks. J Korean Soc Food Sci Nutr, 39, 301-307

4. Lee HS, Park YS, Bai DH (2014) Quality characteristics of Makgeolli (rice wine) fermented with Koji by starch types. Food Eng Prog, 18, 215-221

5. Park CS, Lee TS (2002) Quality characteristics of Takju prepared by wheat flour Nuruks. Korean J Food Sci Technol, 34, 269-302

6. Kim BH, Eun JB (2012) Physicochemical and sensory characteristics of Makgeolli with pomegranate (Punica granatum L.) juice concentrate added. Korean J Food Sci Technol, 44, 417-421

7. Seog HM (2010) Physicochemical characterization of barley. Food Culture, 3, 302-305

8. Lee JS, Lee TS, Park SO, Noh BS (1996) Flavor components in mash of Takju prepared by different raw materials. Korean J Food Sci Technol, 28, 316-323

9. Han EH, Lee TS, Noh BS, Lee DS (1997) Volatile flavor components in mash of Takju prepared by using different Nuruk Korean J Food Sci Technol, 29, 563-570

10. So MH, Lee YS, Han SH, Noh WS (1999) Analysis of major flavor compounds in Takju mash brewed with a modified Nuruk Korean J Food \& Nutr, 12, 421-426

11. Kim HR, Kwon YH, Jo SJ, Kim JH, Ahn BH (2009) Characterization and volatile flavor components in glutinous rice wines prepared with different yeasts of Nuruks. Korean J Food Sci Technol, 41, 296-301

12. Kim SH, Mun JY, Kim SY, Yeo SH (2018) Quality characteristics of glutinous rice-Makgeolli fermented with Korean yeast (SC Y204 and Y283) isolated from Nuruk Korean J Food Preserv, 25, 874-884

13. Roh HI, Chang EH, Joeng ST, Jahng KY (2008) Characteristics of fermentation and wine quality. Korean J Food Preserv, 15, 317-324

14. Lee CH, Tae WT, Kim GM, Lee HD (1991) Studies on the pasteurization conditions of Takju. Korean J Food Technol, 23, 44-51

15. Joung EJ, Paek NS, Kim YM (2004) Studies on Korean Takju using the by-product of rice milling. Korean J Food Nutr, 17, 199-205

16. So MW, Lee YS, Noh WS (1999) Changes in microorganisms and main components during Takju brewing by a modified Nuruk J Food Nutr, 12, 226-232

17. Song JC, Park HJ, Shin WC (1997) Change of Takju qualities by addition of cyclodextrin during the brewing and aging. Korean J Food Sci Technol, 29, 895-900
18. Jin TY, Wang MH, Yin Y, Eun JB (2008) Effect of Cirus junos peel on the quality and antioxidant activity of traditional rice wine, Jinyangju. J Korean Soc Food Sci Nutr, 37, 76-82

19. Han EH, Lee TS, Noh BS Lee DS (1997) Quality characteristics in mash of Takju prepared by using different nuruk during fermentation. J Korean Food Sci Technol, 29, 555-562

20. Lee SM, Lee TS (2000) Effect of roasted rice and defatted soybean on the quality characteristics of Takju during fermentation. J Nat Sci, 12, 71-79

21. Kim JY, Sung KW, Bae HW, Yi YH (2007) pH, acidity, color, reducing sugar, total sugar, alcohol, and organoleptic characteristics of puffed rice powder added Takju during fermentation. Korean J Food Sci Technol, 39, 266-271

22. Kim CJ (1968) Microbiological and enzymological studies on Takju brewing. J Korean Soc Appl Biol Chem, $10,69-100$

23. Yu H, Ding YS, Mou SF (2003) Direct and simultaneous determination of amino acids and sugars in rice wine by high-performance anion-exchange chromatography with integrated pulsed amperometric detection. J Chromatogr, 57, 721-728

24. Cheong C, Rhee IS, Lee SK, Kang SA (2008) A study on the qualitative properties of traditional sake using allbanggae. J Korean Soc Food Sci Nutr, 37, 784-791

25. Im CY (2012) Quality characteristics of persimmon Makgeolli on the processing forms of added persimmon and containing persimmon. MS Thesis, Kyungpook National University, Korea, p 2-6

26. Choi JH, Jeon JA, Jung ST, Park JH, Park SY, Lee $\mathrm{CH}$, Kim TJ, Choi HS, Yeo SH (2011) Quality characteristics of Seoktanju fermented by using different commercial Nuruks. Korean J Microbiol Biotechnol, 39, 56-62

27. Ji SH, Han WC, Lee JC, Kim BW, Jang KH (2009) Fermentation characteristics of moru wine fermented with Rose rugoga Thun. Korean J Food Sci Technol, 41, 186-190

28. Lee YJ, Yi HC, Hwang KT, Kim DH, Kim HJ, Jung CM, Choi YH (2012) The qualities of Makgeolli (Korean rice wine) made with different rice cultivars, milling degrees of rice, and Nuruks. J Korean Soc Food Sci Nutr, $41,1785-1791$ 